\title{
Inflation Thresholds-Financial Development Nexus in South-Eastern Asian Emerging Markets
}

\author{
Kunofiwa Tsaurai \\ University of South Africa, Pretoria, South Africa \\ tsaurk@unisa.ac.za, kunofiwa.tsaurai@gmail.com
}

\begin{abstract}
This paper investigated the maximum inflation threshold levels beyond which financial development declines in the South-Eastern Asian emerging markets using static panel threshold regression framework proposed by Bick (2010) with data ranging from 1994 to 2014. The negative impact of inflation on financial development is a settled matter in both theoretical and empirical literature. However, this study was prompted by recent literature (Boyd et al., 2001; Abbey, 2012; Kim and Lin, 2010) which argued that the relationship between inflation and financial development is not linear and is characterised by inflation thresholds. Moreover, no previous study that the author is aware of used the approach suggested by Bick (2010) to determine inflation threshold levels and financial development. Among previous inflation-finance studies, the current study is the first one according to the author's best knowledge to use banking sector, stock market and bond sector development variables as previous studies were narrow focused in their definition of financial development. The study observed that lower levels of inflation is good for financial development whilst higher levels of inflation slows down the rate at which banking sector, stock and bond markets develop. These results agree with the theory underpinning inflation-financial development nexus. South-Eastern Asian emerging economies are therefore urged to implement macroeconomic policies that ensure inflation rates are kept at lower levels that do not stifle financial development.
\end{abstract}

Keywords: Inflation; Financial Development; Threshold; Panel; Emerging Markets

\section{Introduction and background}

There is consensus in economics with regard to the negative impact of high inflation on economic growth. Two different schools of thought on this subject matter are available: (1) inflation has a direct negative influence on economic growth and (2) inflation indirectly negatively affects economic growth through retarding the rate of development of the financial sector whose intermediation activities are crucial for economic growth. Majority of the empirical studies done on inflation-financial development nexus assumed a linear relationship between the two variables (BenNaceur and Ghazouani, 2005; Wahid et al., 2011; Tolulope and Oyeyinka, 2014; Aboutorabi, 2012). Although the linear relationship between financial sector development and inflation is a resolved matter in economics and finance, very few studies (Boyd et al., 2001; Abbey, 2012; Kim and Lin, 2010) have studied the non-linear relationship between these two variables. These few similar empirical studies on threshold levels of inflation that influence financial development are characterised by some shortcomings: These include the use of a narrow definition of financial development which ignored the bond market, use of outdated data, shied away from the South-Eastern Asian emerging markets region which deserves its own special attention and the use of simplistic threshold regression models. The current study deviates from these previous similar empirical work in the following ways: (1) used the most up to date data available (1994-2014), (2) took a holistic view of the financial sector by separately estimating inflation thresholds-banking sector/stock/bond market development nexus, (3) focused on the largely ignored South-Eastern Asian emerging markets and used the static panel threshold regression model put forward by Bick (2010).

UNCTAD (2016) showed that a meaningful trend exists between inflation and financial development in the South-Eastern Asian emerging markets (see Figure 1 and 2). Empirical researchers on the Asian financial crisis overlooked the fact that inflation could have been one of the factors that indirectly and in a non-linear manner influenced financial development. It is for this reason that the current study employed the static panel threshold regression model to explore the inflation thresholds-financial development in the SouthEastern Asian emerging markets. The rest of the paper is arranged in the following order: The first is theoretical literature followed by empirical literature, inflation-financial development trend analysis, estimation technique, results discussion and summary of the study. 


\section{Literature Review}

According to Haslag and Koo (1999), high inflation levels leads to repression and low development of the financial sector through reducing the importance of holding on to money assets. They asserted that consumers are discouraged to hold on to narrow money and other financial assets that define the depth of the financial system if inflation is high. Ikhide (1992) noted that higher levels of inflation discourage people to hold the quasi-money because it can easily and quickly lose value under such unstable macroeconomic environment. According to Schreft and Smith (1997), interest rate goes up if inflation rate increases thus leading to inefficient financial markets. In addition, high inflation result in the access to real investment return information becoming difficult, uncertain and less smooth flowing and in response, lenders shift their focus to short term objectives rather than long term lending which is not good for financial sector development (Rousseau and Yilmazkuday, 2009:312). Moreover, Tobin (1965) argued that high inflation increases investment levels as consumers move their portfolios from money assets to capital assets in order to shield themselves against the effects of inflation. On the other hand, households in an inflationary environment tend to replace transaction services for money balances hence improving not only the rate at which financial services are produced but the overall financial development (English, 1999).

Review of related empirical literature: Boyd et al. (2001) studied the influence of inflation on financial sector performance in developing countries using the dynamic panel data analysis (GMM estimation technique) with stock market data from 1970 to 1995 and banking sector data ranging from 1960 to 1995. Overall, inflation was found to have had a significant negative impact on financial sector performance. They found out that inflation rate above a threshold level of $15 \%$ led to a negative financial sector performance during the period under study. Abbey (2012) analysed the relationship between financial development and inflation in Ghana using a combination of different types of quantitative data analysis with quarterly time series data ranging from 1990 to 2008.Their findings are fourfold: (1) The use of pair wise correlation observed the existence of a negative relationship between inflation and financial development in Ghana, (2) regression analysis found out that inflation and financial development were positively linked in the short run whereas no relationship between the two variables existed in the long run in Ghana, (3)using private sector credit to GDP ratio and stock market capitalisation proxies, regression analysis showed that inflation positively influenced financial development in Ghana and (4) inflation rates above $16 \%$ threshold level were found to have negatively impacted on financial development whilst inflation rate below a threshold level of $11 \%$ positively influenced financial development. Inflation rates from $11 \%$ to $16 \%$ had a stagnant effect on financial development in Ghana. Kim and Lin (2010) also showed that it is only when inflation exceeds a certain minimum threshold level that informational frictions in the credit markets begin to overall reduce financial sector development.

Gillman and Kejak (2007) found results which supported that inflation negatively influence financial sector development, in line with most empirical findings on the subject matter. Mostafa et al. (2012) studied the impact of inflation on financial sector performance in Iran using the Quintile Econometric Approach. The major weakness of their study is that they used banking sector development proxies as proxies of financial sector performance; hence the study was a narrow focus of the financial sector. The findings are twofold: (1) Higher levels of inflation were found to have had slowed the financial sector's efficiency and effectiveness in performing its intermediary function and (2) inflation negatively influenced the growth of the financial sector in Iran. Table 1 on the next page summarises the empirical research work on inflation and financial development. 
Table 1: A summary of empirical studies on inflation-financial development nexus

\begin{tabular}{lr}
\hline Author & \\
\hline BenNaceur & and \\
Ghazouani & (2005) \\
examined the influence of \\
inflation on financial \\
development.
\end{tabular}

Alimi (2014) examined the impact of inflation on financial sector performance.

Wahid et al. (2011) studied the correlation between the financial sector and inflation.

Tolulope and Oyeyinka (2014) examined the link between inflation and financial sector

Khan et al. (2014) analyzed the influence of inflationary pressure on banking sector performance.

Umar et al. (2014) studied the impact of inflation on banking sector performance.

Middle East and Northern

African (MENA) countries

Nigeria using banking sector development data from 1970 to 2012 .

\section{Country/Countries of study}

Methodology

Dynamic

model

Generalized

Methods

Moments

estimation.

Time series data analysis

Bangladesh using data between 1985 and 2005 .

Sub-Saharan Africa $\quad(45$ countries) with data from 1980 to 2011. Used stock market and banking sector development variables as proxies of financial development.

Pakistan with data from 2009 to 2013.

Developed and developing Conceptual analysis countries

Autoregressive

Distributive Lag (ARDL) and Error Correction Model (ECM).

Panel data analysis.

Trend analysis and regression analysis. performance.

Manoel

(2007) investigated the impact of inflation on financial development.

Almalki and Batayneh (2015) studied the nexus between inflation and financial development.
Brazil with annual data between 1985 and 2002.

Saudi Arabia with annual time series data from 1982 to 2013.
Time series and panel time series data analysis.

ARDL estimation technique was used. Banking sector development proxy was used as a measure of financial development.

Research findings

Inflation negatively affected the performance of the financial sector in the MENA region. They also observed that inflation began to negatively influence financial sector performance when it exceeds a certain threshold level.

Higher inflation was found to have had a negative impact on financial sector performance. On the other hand, low inflation was found to positively influence economic growth through boosting financial sector's intermediation ability.

High levels of inflation impeded the performance and growth of the financial sector in Bangladesh.

Higher inflation negatively affected financial sector performance across all the countries under study.

Inflation and return on assets and inflation and return on equity of the banking sector were positively correlated.

They noted that inflation leads to high banking sector performance as long as banks increase interest rates in anticipation to high inflation in order to gain more revenue. Their study also found out that inflation reduced the purchasing power, loans policy and equity holding performance of banks.

Inflation had a deleterious impact on financial development. High inflation slowed down the rate at which financial development stimulated economic growth in Brazil.

The study revealed that there exist a long run relationship between inflation and financial development in Saudi Arabia during the period under study. Inflation negatively affected financial development both in the long and short run in Saudi Arabia. Previous financial sector's policies positively and significantly influenced financial sector development. 
Rousseau and Wachtel Developing countries

(2000) explored the link between financial development, inflation and economic growth.

Ozturk and Karagoz (2012) investigated the link between economic growth, inflation and financial development.

Rousseau and Wachtel (2002) studied the relationship between inflation and finance. from 1960 to 1995
Turkey using time series data ranging from 1971 to 2009.

84 countries using panel data

$\begin{array}{lr}\begin{array}{l}\text { Aboutorabi } \\ \text { analyzed } \\ \text { between } \\ \text { development } \\ \text { inflation. }\end{array} & \text { financial } \\ \text { fink } & \text { and } \\ & \end{array}$

Barugahara (2012)
60 countries using panel data from 1980 to 2009.

Pakistan using time series data (1974 to 2007).
Panel data analysis using banking sector variables as measures of the financial system.
They found out that high levels of inflation inhibit economic growth through negatively affecting the financial sector's ability to mobilize savings and lend them to the productive sectors of the economy.

ARDL estimation technique using banking sector

The study noted that inflation negatively affected financial development in Turkey. development measures of financial development.

Panel data analysis

An inflation range between $13 \%$ and $25 \%$ was observed beyond which inflation begin to negatively affect financial development's ability to influence economic growth. Inflation was also found to have a negative impact on financial depth in the countries studied.

Higher levels of inflation did not only negatively affect banking system financial development but also reduced the effectiveness and efficiency of the banking sector's intermediation functional duties. Higher inflation was found to have

Generalized Methods

Moments estimation technique. financial sector's ability to reduce income inequality.

Johansen co- The study noted that inflation and integration, F- financial development were coBounds co- integrated. Moreover, inflation was integration test and found to have had a positive Vector Autoregressive approaches. influence on financial development in the long and short run in Pakistan contrary to majority of empirical studies.

Inflation Granger caused financial

Co-integration and error correction

model. sector development in both the long and short run in Kenya. explored the relationship

between inflation and

finance-growth nexus.

\section{(1969-2006)}

\section{Source: Author compilation}

In summary, majority of inflation-financial development studies took a narrow perspective of the financial sector, focused on single countries and avoided emerging markets as a bloc of countries. Moreover, they assumed that there exists a linear relationship between inflation and financial development. Even the few that took into account the non-linearity of the inflation-financial development nexus, they used simplistic threshold regression models.

Inflation and financial development trends in South-Eastern Asian emerging markets: Inflation consumer prices (annual \%) went up by 11.97 percentage points, from $87.52 \%$ in 1994 to $20.49 \%$ in 1999 whilst stock market turnover ratio increased from $29.43 \%$ in 1994 to $33.04 \%$ in 1999 in Indonesia. The 
period between 1999 and 2004 saw inflation consumer prices (annual \%) in Indonesia declining by 14.25 percentage points, further decreased by 1.43 percentage points, from $6.24 \%$ in 2004 to $4.81 \%$ in 2009 before recording a 1.58 percentage points positive growth during the subsequent five year period to close year 2014 at $6.39 \%$. Stock market turnover ratio for Indonesia recorded a 3.17 percentage points negative growth, from $33.04 \%$ in 1999 to $29.87 \%$ in 2004 , went up by 10.18 percentage points during the subsequent five year period (2004 to 2009) before plummeting by 18.55 percentage points, from $40.05 \%$ in 2009 to $21.49 \%$ in 2014. On the other hand, inflation consumer prices (annual \%) for Malaysia marginally went down by 0.98 percentage points, from $3.72 \%$ in 1994 to $2.74 \%$ in 1999 whereas stock market turnover ratio increased by a massive 23.51 percentage points (from $6.49 \%$ in 1994 to $30.06 \%$ in 1999) during the same time period. The five year period between 1999 and 2004 saw inflation consumer prices (annual \%) and stock market turnover ratio for Malaysia declining by 1.23 and 0.22 percentage points respectively. Inflation consumer prices (annual \%) for Malaysia then plummeted by 0.94 percentage points, from $1.52 \%$ in 2004 to $0.58 \%$ in 2009 before recording a 2.56 percentage points positive growth during the subsequent five year period to end the year 2014 at $3.14 \%$. The same trend applies to the stock market turnover ratio for Malaysia which decreased by 1.89 percentage points, from $29.84 \%$ in 2004 to $27.95 \%$ in 2009 before positively growing by 3.13 percentage points during the five year subsequent period (from $27.95 \%$ in 2009 to $31.08 \%$ in 2014 ).

Figure 1: Inflation trends for South-Eastern Asian Emerging Markets

$$
70.00
$$

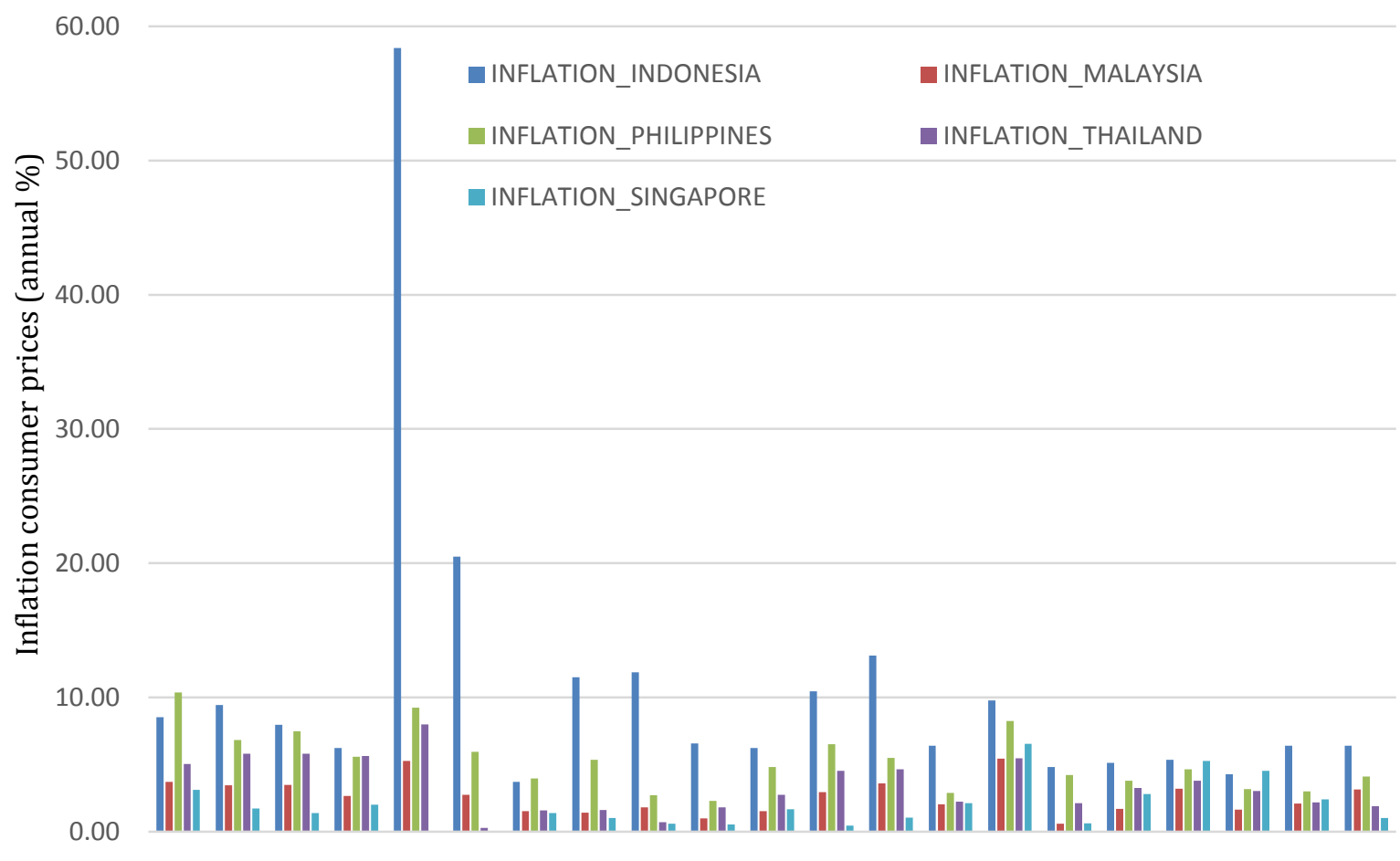

199419951996199719981999200020012002200320042005200620072008200920102011201220132014

Source: UNCTAD (2016)

In Philippines, inflation consumer prices (annual \%) was characterised by a general declining trend during the period from 1994 to 2014 whilst stock market turnover ratios were punctuated by a mixed trend during 
the same time period. Inflation consumer prices (annual \%) plummeted by 4.45 percentage points, from $10.39 \%$ in 1994 to $5.94 \%$ in 1999 before further declining by 1.11 percentage points during the subsequent five year period to end the year 2004 at 4.83\%. Moreover, inflation in Philippines marginally declined by 0.61 percentage points, from $4.83 \%$ in 2004 to $4.22 \%$ in 2009 before recording another slight decrease of 0.11 percentage points during the five year subsequent period to end the year 2014 at $4.10 \%$. Stock market turnover ratio went down from $45.95 \%$ in 1999 to $11.31 \%$ in 2004, increased by 5.28 percentage points during the subsequent five year period (2004 to 2009) and plummeted by 0.46 percentage points, from $16.58 \%$ in 2009 to $16.12 \%$ in 2014 .

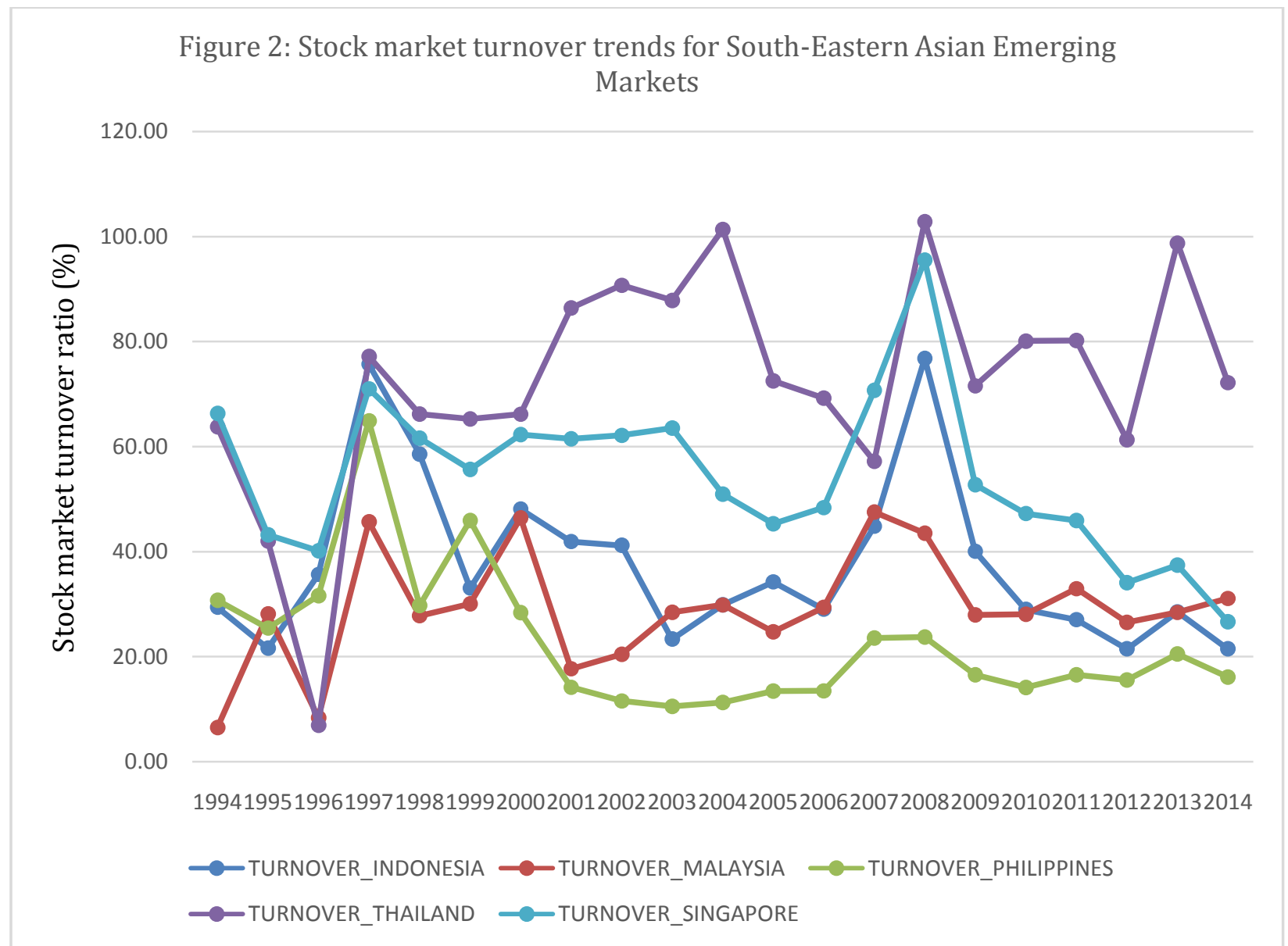

Source: UNCTAD (2016)

In Thailand, inflation consumer prices (annual \%) declined by 4.76 percentage points, from $5.05 \%$ in 1994 to $0.28 \%$ in 1999 whilst stock market turnover ratio increased by $1.49 \%$ during the same period (from $63.76 \%$ in 1994 to $65.25 \%$ in 1999). Both inflation and stock market turnover for Thailand went up by 2.47 and 36.09 percentage points respectively during the period from 1999 to 2004. Inflation measured by consumer prices (annual \%) marginally decreased by 0.63 percentage points, from $2.76 \%$ in 2004 to $2.13 \%$ in 2009 whilst stock market turnover ratio massively declined by 29.78 percentage points during the same time frame (from $101.34 \%$ in 2004 to $71.56 \%$ in 2009). Thailand saw inflation rate further declining by 0.24 percentage points whilst stock market turnover ratio increased by 0.61 percentage points during the subsequent five year period to end the year 2014 at $1.89 \%$ and $72.17 \%$ respectively. Singapore was characterised by a decline in both inflation and stock market turnover ratio during the five year period from 1994 to 1999. The latter went down from $3.10 \%$ in 1994 to $0.02 \%$ in 1999 whereas stock market turnover ratio plummeted by a huge margin, from $66.29 \%$ in 1994 to $55.66 \%$ in 1999. Moreover, inflation for Singapore increased by 1.65 percentage points, from $0.02 \%$ in 1999 to $1.66 \%$ in 2004, declined by 1.06 percentage points from 2004 to 2009 and then surged by 0.41 percentage points, from $0.60 \%$ in 2009 to $1.01 \%$ in 2014 . On the other hand, 
stock market turnover ratio of Singapore decreased by 4.71 percentage points, from $55.66 \%$ in 1999 to $50.95 \%$ in 2004 , marginally increased by 1.80 percentage points during the subsequent five year period (2004 to 2009) before massively declining by 26.10 percentage points, from $52.74 \%$ in 2009 to $26.65 \%$ in 2014.

\section{Estimation technique, results discussion and interpretation}

This section covers data, data sources, variables used, the estimation technique employed, results summary, discussion and interpretation.

Data and variables used: This study used financial development as a dependent variable, inflation as an independent variable and control variables (trade openness, economic growth and FDI) ranging from 1994 to 2014 for South-Eastern Asian emerging markets. Inflation consumer prices (annual \%) was used as a measure of inflation, stock market turnover ratio as a proxy for stock market development, domestic credit by banks to the private sector (\% of GDP) as a proxy for banking sector development whilst outstanding domestic private debt securities as a ratio of GDP was used as a measure of bond market development. Following Nobakht and Madani (2014), this study converted all the data into natural logarithms before any threshold regression analysis could be done in an attempt to do away with data abnormality and autocorrelation bias.

Economic growth, FDI and trade openness were used as control variables, consistent with empirical evidence. For example, Saleryd and Vlachos (2002); Huang and Temple (2005) argued that openness of the economy spur financial development through attracting foreign and domestic investment into the financial system. Shahbaz and Rahman (2010) showed that FDI inflows boost financial markets competition thereby making them more efficient. Levine (1997) revealed that FDI improve both stock market and banking sector liquidity as it brings along huge capital injection into the host country. Proponents of the demand following hypothesis such as Robinson (1952) and Patrick (1966) postulated that economic growth increases the demand of financial services which lead to the introduction of new financial sector firms in order to meet the increased demand for financial services. The secondary data for the dependent, independent and control variables was obtained from UNCTAD (2016) and World Bank (2015), databases which are quite reputable internationally. In line with literature, inflation is expected to negatively influence financial development whilst trade openness, FDI and economic growth are expected to have a positive impact on financial development. The general financial development model for this study is summarised in equation 1.

$F D=$ f(INFLATION, ECONOMIC GROWTH, TRADE OPENNESS, FDI). [1]

Whereas inflation is the chief determinant of financial development in this paper, other factors such growth, openness and FDI have also been identified by literature as significant explanatory variables of financial development.

Econometric estimation framework: Bick (2010) critiqued the original static panel threshold regression model founded by Hansen (1999) by arguing that failure to include the regime intercepts in the model cause variable omitting bias in the estimation of threshold co-efficients and the regression slope. The general model of Bick (2010) is as follows:

$y_{\mathrm{it}}=\mu_{\mathrm{i}}+\beta_{1} x_{\mathrm{it}} \mathrm{I}\left(x_{\mathrm{it}} \leq \gamma\right)+\delta_{\mathrm{i}} \mathrm{I}\left(x_{\mathrm{it}} \leq \gamma\right)+\beta_{2} x_{\mathrm{it}} \mathrm{I}\left(x_{\mathrm{it}}>\gamma\right)+\varphi z_{\mathrm{it}}+$ Eit $\quad$ [2]

$y_{\mathrm{it}}$ is the ratio of economic growth as a ratio of GDP for country i at time $t, \mu_{\mathrm{i}}$ is the specific country fixed effect;

$\beta_{1}$ and $\beta_{2}$ are the slope coefficients, $\gamma$ represents the threshold level, $\varphi z_{i t}$ stands for control variables, $\mathrm{z}_{\mathrm{it}}$ represents a vector of conditional information set of explanatory regressors which include the exogenous variables. $X_{i t}$ is threshold variable which is exogenous whilst $\delta_{i}$ stands for the regime intercepts. I stands for the indicator function for non-linearity between inflation and growth whilst ( $E i t$ ) is the error term. The theoretical foundation of Bick (2010) model is that there is a maximum level of inflation beyond which 
economic growth is negatively influenced. Similarly, the theoretical bedrock of this study is that there is a maximum threshold level of inflation rate above which financial development begins to be negatively affected. Modified equations describing the relationship between inflation and financial development is as follows, consistent with Bick (2010) approach.

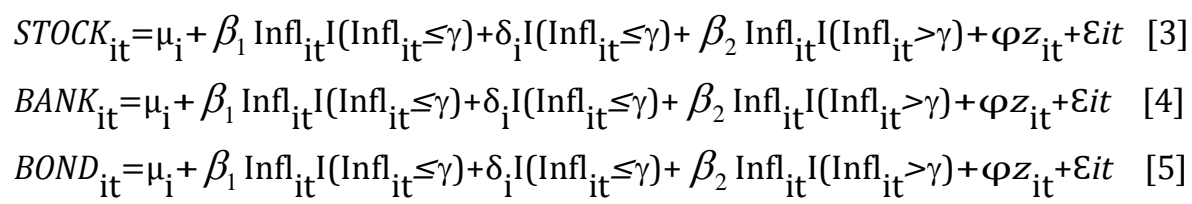

Where STOCK $_{i t}$ is the stock market development for country i at time $t$, BANK $_{\text {it }}$ stands for banking sector development for country $i$ at time $t$ and $\mathrm{BOND}_{i t}$ is the bond market development for country $i$ at time $t$. The independent variable Infl $_{\text {it }}$ represents inflation for country i at time $t$.

Following Bick (2010), the author eliminated the specific fixed effects using the standard within transformation method before employing the ordinary least squares (OLS) to estimate the threshold levels which must be reached before inflation begins to retard or negatively affect financial sector development.

\section{Results and interpretation}

Table 2 shows the results of the static panel threshold estimation technique.

Table 2: Results of the Bick' (2010) panel threshold regression model

\begin{tabular}{|c|c|c|c|c|c|c|}
\hline \multirow{3}{*}{$\begin{array}{l}\text { Threshold } \\
\text { Estimate }\end{array}$} & \multicolumn{3}{|c|}{ Model 1:STOCK= f(inflation, controls) } & \multicolumn{3}{|c|}{ Model 2:BANK= f(inflation, controls) } \\
\hline & $5.95 \%$. & \multicolumn{2}{|c|}{ C.I.[4.43\%-5.99\%] } & $5.91 \%$. & \multicolumn{2}{|c|}{ C.I.[5.88\%-6.17\%] } \\
\hline & Coefficient & Std. error & T statistic & Coefficient & Std. error & T statistic \\
\hline$\beta_{1}$ & 0.2668 & 0.4782 & 0.5584 & $0.5003^{* *}$ & 0.2401 & 2.0837 \\
\hline$\beta_{2}$ & 0.3671 & 0.8926 & 0.4113 & 0.1937 & 0.2197 & 0.8817 \\
\hline$\delta_{\mathrm{i}}$ & -1.3892 & 0.9953 & -1.3958 & -1.0027 & 0.7027 & -1.4269 \\
\hline Growth & 0.3346 & 0.9372 & 0.3570 & 0.0031 & 0.0484 & 0.0641 \\
\hline Openness & -0.0626 & 0.9028 & -0.0693 & -0.2017 & 0.9022 & -0.2236 \\
\hline \multirow[t]{2}{*}{ FDI } & $0.2448^{*}$ & 0.1286 & 1.8974 & $0.4902^{* *}$ & 0.2196 & 2.2322 \\
\hline & \multicolumn{6}{|c|}{ Model 3: BOND= f(inflation, controls) } \\
\hline \multirow{2}{*}{$\begin{array}{l}\text { Threshold } \\
\text { Estimate }\end{array}$} & $4.89 \%$ & ..I. $[4.47 \%-5$ & & & & \\
\hline & Coefficient & Std. error & T statistic & & & \\
\hline$\beta_{1}$ & 0.6639 & 0.5823 & 1.1401 & & & \\
\hline$\beta_{2}$ & 0.0327 & 0.0723 & 0.4523 & & & \\
\hline$\delta_{\mathrm{i}}$ & -0.9804 & 0.1710 & -5.7333 & & & \\
\hline Growth & 0.2217 & 0.9871 & 0.2246 & & & \\
\hline Openness & $0.6739^{* *}$ & 0.2902 & 2.3222 & & & \\
\hline FDI & 0.4218 & 0.3018 & 1.3976 & & & \\
\hline
\end{tabular}

$* / * * /^{* * *}$ indicate $10 \% / 5 \% / 1 \%$ respectively

Inflation rate below or equal to the threshold of 5.95\% positively influenced stock market development whilst inflation above the same threshold level more positively boosted stock market development in the South-Eastern Asian emerging markets. In other words, a 1\% increase in inflation at levels less or equal to a $5.95 \%$ threshold led to a $26.68 \%$ increase in stock market development whilst a $1 \%$ in inflation at levels above the threshold resulted in stock market development going up by $36.71 \%$. This is contrary to most literature on this subject which says that higher levels of inflation negatively affect financial development. 
However, this finding still resonate with Tobin (1965) whose study suggested that that high inflation increases investment levels as consumers move their portfolios from money assets to capital assets to shield themselves against the effects of inflation. The finding is also consistent with English (1999) who argued that households in an inflationary environment replace transaction services for money balances hence improving not only the rate at which financial services are produced but the overall financial development.

Inflation levels below or equal to a threshold of 5.91\% positively and significantly impacted on banking sector development whereas inflation levels above the threshold positively but non-significantly influenced banking sector development in South-Eastern Asian emerging markets. The size of the co-efficients shows that the levels of inflation below or equal to the threshold more positively affected banking sector development whereas the levels of inflation above the threshold had a smaller positive and insignificant impact on banking sector development in South-Eastern Asian emerging markets. Moreover, inflation levels below or equal to the threshold of $4.89 \%$ had a more positive impact on bond sector development whilst inflation levels above the threshold had a weak positive influence on bond sector development in South-Eastern Asian emerging markets. The results of the relationship between inflation and financial development support literature (Umar et al., 2014) which says that higher levels of inflation do not necessarily negatively affect financial development but reduce the rate of financial development. The findings also resonate with Boyd et al. (2001) whose study revealed that inflation below a certain threshold had a positive influence on financial development whilst inflation above a threshold negatively affected financial development in developing countries. Economic growth and FDI positively influenced banking sector, bond and stock market in line with literature (Saleryd \& Vlachos, 2002; Huang \& Temple, 2005; Shahbaz \& Rahman, 2010; Levine, 1997). Openness contradicted the theory in model 1 and 2 and agreed with literature in model 3 . The possible reason for the contradiction could be that high levels of openness could have allowed or facilitated some investors to offload their shares at the local stock exchange.

\section{Conclusion}

This study investigated the existence of inflation thresholds in the inflation-financial development nexus in the South-Eastern Asian emerging markets using the static panel threshold regression framework proposed by Bick (2010). The negative impact of inflation on financial development is a settled matter in both theoretical and empirical literature. However, this paper was prompted by recent literature (Boyd et al., 2001; Abbey, 2012; Kim and Lin, 2010) which suggested the relationship between inflation and financial development is not linear and is characterised by inflation threshold levels. The study found out that lower levels of inflation is good for financial development whilst higher levels of inflation slows down the rate at which banking sector, stock and bond markets develops in line with Kim and Lin (2010) who found that it is only when inflation exceeds a certain minimum threshold level that informational frictions in the credit markets begin to overall reduce financial sector development. They also concur with Gillman and Kejak (2007) whose study noted that higher levels of inflation slowed the rate of financial sector's efficiency and effectiveness in performing its intermediary function in Iran. The authorities in the South-Eastern Asian emerging economies are therefore urged to implement macroeconomic policies that ensure inflation rates do not exceed the threshold levels estimated by this study in order to guarantee sustainable growth of their financial systems. Economic growth policies and FDI attraction strategies should be implemented by the South-Eastern Asian emerging markets if they intend to develop their financial markets.

\section{References}

Abbey, E. N. (2012). Inflation and financial development: Evidence. American Journal of Economics and Business Administration, 4(4), 227-236.

Aboutorabi, M. A. (2012). The effect of inflation on financial development: The case of Iran. Journal of Basic Applied Sciences, 2(8), 8394-8400.

Alimi, R. S. (2014). Inflation and financial sector performance: The case of Nigeria. Timisoara Journal of Economics and Business, 7(1), 55-69.

Almalki, A. \& Batayneh, K. (2015). The relationship between inflation and financial development in Saudi Arabia. Proceedings of the Australasian Conference on Business and Social Science 2015, Sydney (in partnership with The Journal of Developing Areas), 421-427. 
Barugahara, F. (2012). Financial development and income inequality: Does inflation matter? Applied Economics Quarterly, 58(3), 193-212.

BenNaceur, S. \& Ghazouani, S. (2005). Does inflation impact on financial sector performance in the MENA region? Review of Middle East Economics and Finance, 3(3), 219-229.

Bick, A. (2010). Threshold effects of inflation on economic growth in developing countries. Economic Letters, 108(2), 126-129.

Boyd, J. H., Levine, R. \& Smith, B. D. (2001). The impact of inflation on financial sector performance. Journal of Monetary Economics, 47(2), 221-248.

English, W. B. (1999). Inflation and financial sector size. Journal of Monetary Economics, 44(3), 379-400.

Gillman, M. \& Kejak, M. (2007). Inflation, financial development and human capital based endogenous growth: An explanation of ten empirical findings. Centre for dynamic macroeconomic analysis, Conference Papers 2007, Number CDMC07/03.

Hansen, B. E. (1999). Threshold effects in non-dynamic panels: Estimation, testing and inference. Journal of Econometrics, 93(2), 345-368.

Haslag, J. \& Koo, J. (1999). Financial repression, financial development and economic growth, Federal Reserve Bank of Dallas, Working Paper Number 99-02.

Huang, Y. \& Temple, J. (2005). Does external trade promote financial development? CEPR Discussion Papers Number 5150.

Ikhide, S. (1992). Financial deepening, credit availability and the efficiency of investment: Evidence of selected African countries. Development Research Paper Series, Research Paper Number 2.

Khan, W. A., Shahid, M., Bari, R., Anam, W., Shehzad, N. \& Siddique, S. (2014). Impacts of inflationary trends on banks' performance (Large Banks Segment) in Pakistan. International Journal of Accounting and Financial Reporting, 4(1), 296-305.

Kim, D. H. \& Lin, S. C. (2010). Dynamic relationship between inflation and financial development. Macroeconomic Dynamics, 14(3), 343-364.

Levine, R. (1997). Stock markets, economic development and capital control liberalisation. Perspectives, 3(5), 1-7.

Manoel, B. (2007). Inflation and financial development: Evidence from Brazil. Proceedings of the German Development Economics Conference, in cooperation with Research Committee on Development Economics, German Economic Association, No. 1.

Mostafa, S., Saba, M., Malihe, H. \& Hoda, Z. S. (2012). The impact of inflation on financial sector performance in Iran. Quarterly Journal of Applied Economics Studies, 1(2), 177-215.

Nobakht, M. \& Madani, S. (2014). Is FDI spill-over conditioned on financial development and trade liberalisation: Evidence from UMCs. Journal of Business and Management Sciences, 2(2), 26-34.

Odhiambo, N. M. (2009). Finance-growth nexus and inflation dynamics in Kenya: An empirical investigation. Savings and Development, 33(1), 7-25.

Ozturk \& Karagoz, K. (2012). Relationship between inflation and financial development: Evidence from Turkey. International Journal of Alanya Faculty of Business, 4(2), 81-87.

Patrick, H. T. (1966). Financial development and economic growth in underdeveloped countries. Economic Development and Cultural Change, 14(2), 174-189.

Robinson, J. (1952). The generalisation of the general theory: The rate of interest and other essays, London: MacMillan Publishing Company, 67-142.

Rousseau, P. L. \& Wachtel, P. (2000). Inflation, financial development and growth. Economic Theory, Dynamics and Markets: Essays in Honour of Ryuzo.

Rousseau, P. L. \& Wachtel, P. (2002). Inflation thresholds and the finance-growth nexus. Journal of International Money and Finance, 21(6), 777-793.

Rousseau, P. L. \& Yilmazkuday, H. (2009). Inflation, financial development and growth: A trilateral analysis. Economic Systems, 33(4), 310-324.

Saleryd, H. \& Vlachos, J. (2002). Markets for risk and openness to trade: How are they related? Journal of International Economics, 57(2), 369-395.

Schreft, S. L. \& Smith, B. D. (1997). Money, banking and capital formation. Journal of Economic Theory, 73(1), 157-182.

Shahbaz, M. \& Rahman, M. M. (2010). Foreign capital inflows-growth nexus and the role of domestic financial sector: An ARDL co-integration approach for Pakistan. Journal of Economic Research, 15(3), 207-231.

Tobin, J. (1965). Money and economic growth. Econometrica, 33(4), 71-84. 
Tolulope, A. O. \& Oyeyinka, O. L. (2014). The impact of inflation on financial sector performance: A case study of Sub-Saharan Africa. Indian Journal of Finance, 8(1), 43-50.

UNCTADSTAT (2016) Report.

Umar, M., Maijama, D. \& Adamu, M. (2014). Conceptual exposition of the effect of inflation on bank performance. Journal of World Economic Research, 3(5), 55-59.

Wahid, A. N. M., Shahbaz, M. \& Azim, P. (2011). Inflation and financial sector correlation: The case of Bangladesh. International Journal of Economics and Financial Issues, 1(4), 145-152.

World Bank . (2015). World Development Indicators published by the World Bank, Washington D.C.

Zaman, K., Ikram, W. \& Ahmad, M. (2010). Impact of financial development on inflation: Evidence from Pakistan. Pakistan Journal of Social Sciences, 30(1), 31-44. 